\title{
IMPLEMENTASI PEMBELAJARAN KETERAMPILAN KERAJINAN DENGAN PENDEKATAN PEMBERDAYAAN POTENSI SENI KERAJINAN DAERAH SETEMPAT
}

\author{
Martono \\ (FBS Universitas Negeri Yogyakarta, HP 08156886807, \\ email: martonouny@yahoo.com)
}

\begin{abstract}
Craft Skills Learning Through an Approach that Empowers Local Crafts. Craft skills education equips students with practices aiming to make them possess skills through appreciation and creativity activities to produce craft products so that they acquire life skills. Such learning should give them actual learning experiences. It can be carried out by selecting traditional crafts in a particular region and modifying them into modern crafts developed in accordance with the students' and society's needs. It can be conducted by means of the OIA (Observe, Imitate, and Add) method to make the students acquire art and craft skills. Craft skills education should employ the contextual approach so that what happens in the learning process at school is identical to what exists in society. An important point that teachers should note is how they can play roles as facilitators and totivators for their students, so that the students' competence can develop to the maximum.
\end{abstract}

Keywords: craft learning, art potential learning

\section{PENDAHULUAN}

Untuk memasuki era globalisasi pada melinium ketiga, banyak tantangan yang harus dihadapi dunia pendidikan. Oleh karena itu, para ahli pendidikan dan pemerintah perlu mengantisipasi dan proaktif di dalam mempersiapkan sumber daya manusia memasuki dunia baru tersebut. Masyarakat abad 21 adalah masyarakat yang terus menerus mengejar kualitas dan keunggulan. Sejalan dengan itu menjadi pertanyaan bagaimana dunia pendidikan mampu mengembangkan proses yang berkesinambungan sesuai perkembangan tun- tutan zaman dan kebutuhan masyarakat.

Proses pendidikan adalah proses kebudayaan. Pembelajaran harus dapat mengembangkan potensi anak didik secara maksimal sesuai budaya yang berkembang. Pendidikan masih menganggap siswa sebagai objek yang harus menerima apa saja yang diberikan guru perlu diganti dengan sistem pendidikan yang dapat mengembangkan kemampuan peserta didik (empowering of people). Orientasi pendidikan kita terlalu menekankan pada aspek kognitif saja, sedangkan aspek-aspek kepribadian lainnya yang lebih penting seperti aspek 
afektif terus diabaikan. Hal ini menunjukan bahwa sumbangan pendidikan terhadap peningkatan wawasan dan apresiasi terhadap kesenian dan kebudayaan. Dengan kata lain dunia pendidikan perlu dipacu untuk secara berencana dan terarah melahirkan manusia-manusia budaya yang sadar, terdidik, dan berkualitas.

Para ahli pendidikan mengakui bahwa setiap anak atau individu memiliki potensi yang berbeda-beda, baik dalam perasaan, hasrat, nafsu, dan kehidupan dalam kepribadiannya. Pendekatan belajar harus dapat mengembangkan potensi anak yang berbeda tersebut, dengan memanfaatkan potensi seni yang ada di lingkungan masyarakatnya. Pendidikan merupakan suatu proses interaksi antara pendidik dan peserta didik dalam masyarakat kecil yang disebut kelas. Interaksi antara guru dan siswa dalam kelas hendaknya sepadan dengan budaya seni apa yang terjadi di masyarakat sehingga anak tidak asing dengan budayanya. Dalam proses interaksi ini terjadi tranformasi budaya dari generasi tua (guru) kepada generasi muda (peserta didik). Tilaar (1999:9) mengatakan bahwa pendidikan adalah suatu proses yang menaburkan benihbenih budaya dan peradaban manusia yang hidup dan dihidupi oleh nilainilai atau visi yang berkembang atau dikembangkan di dalam suatu masyarakat. Hal ini dinamakan pendidikan sebagai suatu proses pembudayaan. Penaburan benih dalam proses pembelajaran jika salah akan berakibat negatif bagi para tamatan pendidikan tersebut. Sudah saatnya pendidikan dasar dan menengah mulai memperbaiki sistem yang mencakup kurikulum, cara atau model pembelajaran, penyiapan bahan ajar, dan sarana prasarana.

Pembelajarandi sekolah harus mampu mengadaptasi kemujuan teknologi, memberikan wawasan apreasiasi budaya untuk membentuk lulusan yang memiliki kesadaran dan pemahaman budayanya. Pembelajaran kerajinan pada dasarnya adalah memberikan pengetahuan dan keterampilan dasar yang luas untuk pengembangan kepekaan artistik dan kreativitas agar siswa memiliki adaptabilitas dan fleksibilitas dalam berkarya seni. Seperti diungkapkan Djohar (1999:128), manusia budaya dapat dinilai dari kenerjanya, dipandang dari demensi pengetahuan, cara berpikir, sikap perilaku, cara kerja, dari melihat dan menanggapi serta memecahkan masalah. Apabila pendidikan dianggap sebagai proses yang menghasilkan manusia budaya, proses pembelajaran harus kondusif, perlu perencanaan yang matang. Selanjutnya, apakah kesiapan pendidik dan peserta didik telah diprogram ke arah budaya mengajar dan budaya belajar yang lebih baik.

Pendidikan berwawasan budaya membuat peserta didik yang belajar seni memiliki kinerja seperti seniman, peserta didik yang belajar sains memiliki kinerja seperti saintis. Hanya pada orang yang memiliki budaya seni yang dapat menghasilkan seni dan hanya pada mereka yang memiliki budaya ilmu yang dapat menghasilkan ilmu. Untuk mewujudkan budaya seni dan budaya ilmu kepada peserta didik, mereka disyaratkan untuk diasimilasikan dengan proses seni dan proses sains 
dalam proses belajarnya. Harapan akhir dari semua perubahan pendidikan itu adalah terwujudnya manusia terampil, profesional di bidangnya, manusia yang berbudaya yang mampu mengubah dan menjadikan dirinya menjadi lebih baik. Manusia berbudaya (Tilaar, 1999) adalah seorang yang menguasai dan berperilaku sesuai dengan nilai-nilai budaya, khususnya nilai-nilai etis dan moral yang hidup dalam kebudayaan tersebut.

Proses pembelajaran pada dasarnya adalah proses pembudayaan. Proses pembudayaan pada prinsipnya adalah proses internalisasi nilai-nilai eksternal terhadap seseorang atau masyarakat. Proses internalisasi kebudayaan bersifat hidup dan berkembang secara dinamis sesuai perkembangan jaman. Cara pembudayaan melalui proses asimilasi merupakan internalisasi nilai-nilai eksternal yang benar-benar terintegrasi menyatu dalam diri seseorang. Cara asimilasi merupakan cara yang paling tepat untuk proses internalisasi budaya (Djohar 1999:127). Seni budaya tradisi lokal daerah setempat di negara kita sangat beragam belum terakomudasi dalam pembelajaran di sekolah, untuk itu sudah pada saatnya untuk memasukan seni dan kerajinan dalam pembelajaran di sekolah dalam rangka melestarikan dan mengembangkan budaya setempat.

Pendidikan yang didasarkan pada kebudayaan menuntut pranata sosial seperti keluarga, sekolah haruslah menjadi pusat pengembangan budaya lokal dan nasional. Namun apa yang terjadi sekolah sebagai pengembang kebudayaan masih baru aspek intelektual saja. Sedangkan aspek kepribadian lain yang lebih esensial belum tersentuh. Kebudayaan bersifat dinamis terus berkembang, jika para pelaku kebudayaan tidak dikembangkan potensinya melalui proses pendidikan, akan terjadi proses sosialisasi budaya yang terhambat. Tilaar (1999:177) mengatakan bahwa pendidikan nasional dewasa ini telah terpisah dari kebudayaan, baik kebudayaan daerah maupun kebudayaan nasional. Hal ini perlu diintegrasikan kembali sehingga pendidikan betul-betul hidup, dihidupi, dan menghidupi kebudayaan.

Melihat lulusan sekolah kita yang hanya menguasai aspek pengetahuan akademik tingkat rendah dan belum memiliki kecakapan hidup untuk siap mandiri, aktivitas lulusan sekolah masih banyak bermain game, nongkrong dipinggir jalan, merokok, bahkan sampai melakukan tindak kejahatan. Atas dasar tersebut, pendidikan keterampilan perlu diberdayakan di sekolah agar dapat memberikan keterampilan kepada anak untuk mandiri di masyarakat sesuai konteks budayanya. Atas dasar kondisi masyarakat kita saat ini, negara kita memiliki budaya tradisi, kerajinan yang beraneka ragam mulai ditinggalkan oleh generasi masyarakat pendukungnya. Hal ini dikarenakan dunia pendidikan kurang mengakomodasi potensi budaya lokal dalam kurikulum dan pembelajaran di sekolah. Dalam Standar Isi tersebut, apresiasi seni daerah setempat, nusantara, dan macanegara, tetapi para guru belum mampu memahami dan mengambil keputusan untuk mengimplementasikan dalam pembelajaran secara benar. Pembelajaran di sekolah masih bersifat rutinitas, 
belum ada inovasi sama sekali. Hal itu menyebabkan generasi bangsa ini mulai tidak mengenal budayanya sendiri, meninggalkan budayanya sendiri atau mereka asing dari budayanya sendiri. Kapan lagi kalau tidak sekarang penataan kembali pendidikan keterampilan kerajinan diintegrasikan kembali dengan kebudayaan dan kehidupan lingkungan masyarakat pendukungnya. Harapannya pendidikan betul-betul hidup, dihidupi, dan menghidupi kebudayaan. Kurikulum KBK yang dikemas dalam KTSP dengan pendekatan pembelajaran kontekstual akan memberikan kesempatan tiap daerah atau sekolah untuk ikut bertanggung jawab mengembangkan dan melestarikan seni budaya tradisi/ lokal di tiap daerah tempat sekolah tersebut berada.

KBK telah menerapkan konsep pendidikan berorientasi kecakapan hidup (life skill) agar tamatan memiliki bekal untuk menghadapi permasalahan hidup sehari-hari di keluarga ataupun masyarakat dan pendekatan kontekstual agar yang terjadi dalam proses belajar di sekolah identik dengan budaya yang ada di masyarakat. Sekarang sudah saatnya menyiapkan anak dengan pendidikan keterampilan kerajinan melalui kegiatan pengalaman belajar siswa dengan pola, konsep, dan model baru yang dapat mengembangkan pengalaman estetis, berkreativitas, berapresiasi melalui pembelajaran seni melalui seni, belajar seni tentang seni. Pendidikan keterampilan siap untuk membantu pengembangan anak dalam konsep pendekatan live skills yang menyiapkan anak untuk memiliki kecakapan hidup yang bermakna dan berguna di kemu- dian hari. Mata pelajaran keterampilan pada dasarnya adalah suatu mata pelajaran yang menyenangkan dan mudah dipelajari jika disajikan secara tepat. Keterampilan dapat dipelajari dan dikuasai sebagai bekal hidup. Oleh sebab itu, mulai pendidikan dasar harus dikenalkan pendidikan keterampilan dengan konsep dan cara yang benar. Apalagi pendidikan dasar dan menengah sudah mulai menerapkan kurikulum berbasis kompetensi dalam bentuk KTSP dapat disiapkan sejak awal potensi seni tradisi masyarakat lingkungan sekolah masuk dalam kurikulum.

\section{KARAKTERISTIK MATA PELAJAR- AN KETERAMPILAN}

Sebagai pedoman keberhasilan pendidikan adalah standar isi yang dijabarkan standar kompetensi dan kompetensi dasar. Standar kompetensi didefinisikan sebagai "pernyataan tentang pengetahuan, keterampilan, dan sikap yang harus dikuasai siswa serta tingkat penguasaan yang harus dikuasai siswa serta tingkat penguasaan yang diharapkan dicapai dalam mempelajari sesuatu mata pelajaran (Center for civics education, 1997:2). Menurut definisi tersebut, standar kompetensi mencakup dua hal, yaitu standar isi (Content standarts), dan standar penampilan (Performance standarts). Standar kompetensi yang mencakup isi berupa pernyataan tentang pengetahuan, sikap, dan keterampilan yang harus dikuasai siswa dalam mempelajarari mata pelajaran tertentu. Standar kompetansi yang mencakup penampilan adalah pernyataan tentang kriteria untuk menentukan tingkat pe-

\footnotetext{
Implementasi Pembelajaran Keterampilan Kerajinan dengan Pendekatan Pemberdayaan
} 
nguasaan siswa terhadap standar isi. Dengan demikian, standar kompetensi diartikan sebagai kemampuan seseorang dalam: (1) melaksanakan tugas/ pekerjaan; (2) mengorganisasikan agar pekerjaan dapat dilaksanakan; (3) melakukan respon dan reaksi yang tepat bila ada penyimpangan dari rancangan semula; dan (4) melaksanakan tugas dan pekerjaan dalam situasi yang berbeda.

Mata pelajaran keterampilan meliputi keterampilan kerajinan dan keterampilan teknologi. Keterampilan kerajinan meliputi kerajinan berbahan alami dan buatan, berbahan lunak dan keras. Bahan alami antara kayu, bambu, tanah liat, rotan dan sebagainya, bahan buatan logam, plastik, plastisin, karet, dan sebagainya. Bahan tersebut untuk dibuat kerajinan tekstil, gerabah, kulit, logam, dan mixed media dengan menggunakan berbagai keteknikan, baik manual maupun semi masinal. Keterampilan teknologi meliputi: pengolahan dan pengawetan makanan dengan manisan, asinan, pengasapan, pengeringan, dan permentasi. Keterampilan elektronika membuat benda bergerak dan berbunyi menggunakan tenaga baterai. Mata pelajaran keterampilan memiliki fungsi mengembangkan kepekaan rasa (sensitivitas), kreativitas, dan terampil dalam membuat karya. Dalam berkarya, siswa dapat mengembangkan cita rasa estetis, mengembangkan etika, kesadaran sosial, dan kesadaran kultural siswa dalam kehidupan bermasyarakat, serta mengembangkan rasa cinta terhadap kebudayaan Indonesia.

Berdasarkan subtansinya, materi pembelajaran keterampilan kerajinan meliputi apresiasi dan kreasi. Pembelajaran apresiasi dapat meliputi penyajian seni, kritik seni, dan pengamatan terhadap hasil seni. Dalam pelaksanaan pembelajaran materi tersebut tidak diberikan secara terpisah, melainkan diberikan secara terpadu dalam bentuk pembelajaran keterampilan bersifat apresiatif dan pembelajaran produktif. Berdasarkan prinsipnya pembelajaran keterampilan ditekankan pada pembelajaran produktif yaitu berkarya keterampilan dan penyajian karya.

Materi pembelajaran keterampilan perlu dikaitkan dengan budaya dan kehidupan masyarakat sekitar atau yang lebih luas. Negara Indonesia memiliki keragaman budaya tradisi yang sangat majemuk, hal ini perlu dikenalkan kepada siswa melalui proses pembelajaran apresiasi di kelas. Oleh karena itu, perlu strategi pembelajaran yang dapat mengembangkan dan melestarikan budaya tradisi di seluruh wilayah Nusantara. Pembelajaran keterampilan dalam bentuk berkarya selain dikenalkan pertimbangan artistik, estetik, fungsi, dan kreativitas, juga perlu dikenalkan aspek moral dan etika, agar siswa memiliki kesadaran akan hidup bersama, perilaku, dan kesadaran hukum dalam kehidupan bersama. Dari tahapan itu siswa diharapkan mengenal etika menjiplak itu kurang baik, mengenal hak cipta, pemalsuan karya tidak dibenarkan, dan bentuk lain yang berhubungan dengan masalah moral dan etika yang berlaku.

Pembelajaran keterampilan perlu dikenalkan kesadaran ekonomi kepada siswa, yaitu dengan adanya profesi seni atau keterampilan tertentu dapat men- 
jadi sumber ekonomi untuk memenuhi kebutuhan hidup di masyarakat. Pembelajaran keterampilan seperti ini diperlukan kunjungan ke galeri, musium, pasar seni, industri kerajinan, restoran, pameran teknologi, dan sejenisnya. Oleh sebab itu, pembelajaran seni kerajinan harus memberikan wawasan yang luas mencakup seni diberbagai daerah, diberbagai kebudayaan, baik kebudayaan Indonesia maupun macanegara.

Pembelajaran keterampilan kerajinan perlu dikenalkan dengan teknologi maju untuk membantu produksi keterampilan. Melalui pembelajaran keterampilan di kelas selain dikenalkan bentuk keterampilan juga perlu dikenalkan teknologi untuk membuat produk keterampilan. Misalnya, dalam kerajinan ada peralatan produksi dengan tenaga listrik seperti ketam, gergaji, bor dan sebagainya. Upaya itu untuk memberikan wawasan teknologi kepada siswa agar tidak gagap teknologi.

Pendidikan Seni Budaya dan Keterampilan memiliki sifat multilingual, multidimensional, dan multikultural. Multilingual bermakna pengembangan kemampuan mengekspresikan diri secara kreatif dengan berbagai cara dan media ekspresi seperti bahasa rupa, ekspresi bahasa bunyi menghasilkan bunyi atau nyanyian yang indah, ekspresi dengan bahasa gerak menghasilkan tari yang indah, dan berbagai perpaduannya. Multidimensional bermakna pembelajaran keterampilan mampu mengembangkan beragam kompetensi meliputi konsepsi (pengetahuan, pemahaman, analisis, evaluasi), apresiasi, dan kreasi dengan cara memadukan secara harmonis unsur estetika, logika, kinestetika, dan etika. Sifat multikultural mengandung makna pendidikan seni budaya dan keterampilan menumbuhkembangkan kesadaran dan kemampuan apresiasi terhadap beragam budaya Nusantara dan mancanegara. Hal ini merupakan wujud pembentukan sikap demokratis yang memungkinkan seseorang hidup secara beradab serta toleran dalam masyarakat dan budaya yang majemuk.

Pendidikan Seni Budaya dan Keterampilan memiliki peranan dalam pembentukan pribadi peserta didik yang harmonis dengan memperhatikan kebutuhan perkembangan anak dalam mencapai multikecerdasan yang terdiri atas kecerdasan intrapersonal, interpersonal, visual spasial, musikal, linguistik, logik matematik, naturalis serta kecerdasan adversitas, kecerdasan kreativitas, kecerdasan spiritual dan moral, serta kecerdasan emosional. Dengan pemahaman dan pelaksanaan pembelajaran keterampilan secara benar dan mampu mengimplementasi potensi seni tradisi lokal ke dalam pembelajaran di kelas, pembelajaran akan mengenalkan budaya sendiri kepada peserta didik. Pengenalan budaya tradisi sendiri kepada anak untuk membekali anak agar mereka tidak mudah larut dengan budaya asing yang tidak sesuai dengan nilai dan moral bangsa kita.

Muatan seni budaya dan keterampilan sebagaimana yang diamanatkan dalam Peraturan Pemerintah Republik Indonesia Nomor 19 tahun 2005 tentang Standar Nasional Pendidikan tidak hanya terdapat dalam satu mata pelajaran karena budaya itu sendiri me- 
liputi segala aspek kehidupan. Dalam mata pelajaran Seni Budaya dan Keterampilan, aspek budaya tidak dibahas secara tersendiri tetapi terintegrasi dengan seni. Karena itu, mata pelajaran Seni Budaya dan Keterampilan pada dasarnya merupakan pendidikan seni yang berbasis budaya atau dengan kata lain pembelajaran seni dan keterampilan dengan pendekatan budaya. Materi budaya sebagai sarana untuk membelajarkan seni dan keterampilan kepada peserta didik.

Pendidikan Seni Budaya dan Keterampilan seperti yang dituangkan dalam standar isi kurikulum bertujuan agar peserta didik memiliki kemampuan sebagai berikut.

- Memahami konsep dan pentingnya seni budaya dan keterampilan.

- Menampilkan sikap apresiasi terhadap seni budaya dan keterampilan.

- Menampilkan kreativitas melalui seni budaya dan keterampilan.

- Menampilkan peran serta dalam seni budaya dan keterampilan dalam tingkat lokal, regional, maupun global.

Ruang lingkup Mata pelajaran Seni Budaya dan Keterampilan dalam standar isi meliputi aspek-aspek sebagai berikut.

- Seni rupa, mencakup pengetahuan, keterampilan, dan nilai dalam menghasilkan karya seni berupa lukisan, patung, ukiran, cetak-mencetak, dan sebagainya.

- Seni musik, mencakup kemampuan untuk menguasai olah vokal, memainkan alat musik, apresiasi karya musik.
- Seni tari, mencakup keterampilan gerak berdasarkan olah tubuh dengan dan tanpa rangsangan bunyi, apresiasi terhadap gerak tari.

- Seni drama, mencakup keterampilan pementasan dengan memadukan seni musik, seni tari dan peran.

- Keterampilan, mencakup segala aspek kecakapan hidup (life skills) yang meliputi keterampilan personal, keterampilan sosial, keterampilan vokasional dan keterampilan akademik.

Di antara keempat bidang seni yang ditawarkan, minimal diajarkan satu bidang seni sesuai dengan kemampuan sumberdaya manusia serta fasilitas yang tersedia. Pada sekolah yang mampu menyelenggarakan pembelajaran lebih dari satu bidang seni, peserta didik diberi kesempatan untuk memilih bidang seni yang akan diikutinya. Pada tingkat dasar mata pelajaran Keterampilan ditekankan pada keterampilan pravokasional, khusus kerajinan tangan, agar anak memiliki wawasan dasar tentang kecakapan hidup.

\section{PELAKSANAAN PEMBELAJARAN KETERAMPILAN KERAJINAN}

Pada prinsipnya mengajar adalah proses yang terjadi pada guru bagaimana menyampaikan materi pelajaran kepada anak didiknya. Mengajar pada prinsipnya adalah membina bagaimana belajar, berpikir, berlatih untuk penguasaan suatu pengetahuan, keterampilan dan perubahan sikap. Menurut Gagne dan Briggs (dalam Margaret 1991:205), pembelajaran dilukiskan sebagai upaya orang yang tujuannya ialah membantu orang belajar. Sementara ini, menurut 
Knowles (Mappa 1994:12), pembelajaran adalah suatu proses dimana perilaku diubah, dibentuk atau dikendalikan. Bila pembelajaran ditekanan pada suatu fungsi, pembelajaran adalah suatu perubahan yang dapat memberikan hasil jika orang berinteraksi dengan informasi (materi, kegiatan, pengalaman). Menurut Dimyati (1999:297), pembelajaran adalah kegiatan guru secara terprogram dalam desain instruksional, untuk membuat siswa belajar secara aktif, yang menekankan pada penyediaan sumber belajar.

Pembelajaran berbasis kompetensi adalah program pembelajaran yang hasil belajar atau kompetensi yang diharapkan dapat dicapai siswa, sistem pembelajaran, dan indikator pencapaian hasil belajar dirumuskan secara tertulis sejak perencanaan dimulai Mc Ashan (Gafur, 2001:5). Dalam pembelajaran kompetensi perlu ditentutak standar kompetensi minimal yang harus dikuasai siswa. Sesuai pendapat tersebut komponen pokok pembelajaran berbasis kompetensi meliputi: (1) kompetensi yang akan dicapai; (2) strategipenyampaian untuk mencapai kompetensi; (3) Sistem evaluasi atau pengujian yang digunakan untuk menentukan keberhasilan siswa dalam mencapai kompetensi.

Dalam belajar keterampilan kerajinan, guru harus dapat memotivasi siswa untuk mampu mengekspresikan idenya dengan baik. Guru membimbing dan mengarahkan anak untuk menemukan dirinya sendiri. Larkin (1981) mengatakan motivasi adalah bagian belajar yang sangat penting. Anak membutuhkan bantuan untuk berpikir, menge- luarkan ide melalui media seni, mereka butuh mengungkapkan pengalaman, mereka butuh komunikasi bentuk visual. Pendekatan belajar seni melalui memotivasi siswa dengan diskusi verbal (verbal discussion), pengalaman visual (visual experience), pengalaman langsung (direct experience), pengalaman atau pengetahuan bahan (material experience), pengalaman sensori melalui pancaindra (sensory experience), dan pengembangan kesadaran berpersepsi (developing perceptive awareness).

Proses pembelajaran seni harus melibatkan anak secara langsung beraktivitas seni seperti yang diungkapkan Mattil (1971) pengulangan aktivitas memberikan kepastian hasil yang dapat menumbuhkan rasa percaya diri. Selanjutnya, dikatakan bahwa seseorang harus melukis untuk belajar melukis, belajar membentuk melalui membentuk, belajar membatik melalui kegiatan membatik. Belajar seni harus terlibat langsung dalam aktivitas seni, bukan sekedar teori seni yang hanya memberikan kemampuan pengetahuan kognitif saja. Belajar seni rupa dan kerajinan adalah belajar penguasaan keterampilan agar mampu mengekspresikan idenya dengan baik dan wajar. Pembelajaran seni dan kerajinan yang baik anak disiapkan atau diasimilasikan dalam proses ber seni dan kerajinan yang sesungguhnya. Anak harus terlibat langsung dalam kegiatan berseni dan kerajinan.

Pembelajaran keterampilan kerajinan harus diarahkan untuk mengembangkan kecakapan hidup (life skill) yang mencakup kecakapan kepribadian, akademik, sosial, dan vokasional. 
Pendidikan keterampilan implementasinya pada tingkatan tertentu harus mempertimbangkan aspek pengembangan dan pelestarian potensi derah (budaya, alam, sosial). Pendidikan keterampilan harus mampu menumbuhkan sikap kooperatif, toleran, kemandirian, profesional, dan kepemimpinan pada diri peserta didik. Prinsip pembelajaran keterampilan kerajinan untuk mengembangkan apresiasi dan kreasi siswa. Pembelajararan keterampilan memberikan pengalaman apresiatif dan kreatif kepada peserta didik. Proses penanaman nilai estetik, terampil, dan kreatif, akan lebih bermakna jika siswa mengalami proses langsung dengan berbagai kegiatan berketerampilan. Pembelajaran keterampilan kerajinan di sekolah memberikan apresiasi kepada siswa sebagai bekal untuk pembentukan pengalaman estetik, pengembangan kreativitas, dan keterampilan siswa dalam mengaktualisasikan gagasannya. Pembelajaran keterampilan kerajinan dapat dilakukan melalu pembelajaran sebagai berikut.

Pembelajaran berkarya bertujuan untuk menghasilkan karya. Aktivitas berkarya dilakukan melalui kegiatan belajar keterampilan kerajinan dengan berbagai pendekatan. Belajar seni tradisi dan keterampilan kerajinan seperti batik, ukir, anyam dapat dilakukan dengan menggunakan metode $3 \mathrm{~N}$ (Niteni, Nirokake, lan Nambahi) yang digunakan dalam pembelajaran di Tamasiswa oleh Ki Hajar Dewantoro. Metode $3 \mathrm{~N}$ atau 3 M (Mengamati, Meniru, dan Mengembangkan). Demikian juga penggunaan metode yang mirip, bahkan secara esensial sama seperti yang disampaikan
Kuncoro (2009) untuk memotivasi perajin dalam mengembangkan industri kreatif, yakni dengan metode ATM (Amati, Tiru, dan Modifikasi). Belajar apapun dimulai dengan niteni atau mengamati objek belajar seni tradisi lokal untuk selanjutnya anak mengkonstruksi pengetahuan untuk membangun konsepsi pada peserta didik. Setelah konsep terbentuk pada pikiran peserta didik selanjutnya dilakukan proses keterampilan dengan cara meniru. Belajar keterampilan apapun pada tingkat yang paling rendah dan sederhana adalah dimulai dari meniru. Setelah penguasaan keterampilan dasar dikuasai dengan niteni dan meniru, selanjutnya peserta didik masuk pada tahapan mengembangkan atau memodifikasi.

Pada tataran mengembangkan atau memodifikasi ini peserta didik harus mengembangkan kreativitas dengan melakukan pencarian secara terus-menerus melalui inquairy, questioning, modeling, learning comunity, problem solving, dan individual learning seperti prinsip pembelajaran kontekstual. Belajar memodifikasi atau mengembangkan dapat dilakukan dengan ekplorasi dan eksperimen dalam mengolah gagasan (konsep), bentuk, dan media, teknik, dengan mengambil unsur dari berbagai bentuk seni (tradisi maupun modern), baik sebagai kegiatan individual maupun kegiatan kelompok. Pembelajaran berkarya atau produktif perlu diciptakan suasana yang kondusif dan menyenangkan sehingga dapat memotivasi siswa dalam berkarya. Memberikan kebebasan kepada siswa untuk menentukan pilihannya agar anak dapat berkreasi dengan baik. Peran guru dalam proses 
berkarya sebagai fasilitator dan mitra kerja siswa. Sebagai fasilitator dan mitra kerja peserta didik harus dapat membimbing dan memotivasi kerja dengan baik.

Pembelajaran apresiasi bertujuan untuk mengembangkan kesadaran, pengalaman, dan penghargaan terhadap proses berkarya dan hasil karya seni. Kegiatan apresiasi dapat dilakukan melalui pengamatan, melakukan percobaan, diskusi, dan pembahasan hasil karya seni. Hasil karya kerajinan sebagai objek kegiatan apresiasi tersebut dapat dalam bentuk karya siswa, foto karya seniman, produk perajin, gambar, rekaman, dan pameran hasil karya. Pengamatan karya bertujuan untuk memperoleh pengalaman estetik melalui pencerapan nilai-nilai instrinsik pada bentuk atau komposisi karya seni untuk membangun konsepsi peserta didik. Pembahasan karya seni bertujuan untuk mendapatkan kesadaran dan pemahaman tentang penciptaan karya, berdasarkan telaah tentang perajin, seniman, latar belakang penciptaan, tujuan penciptaannya. Pembelajaran apresiasi untuk memahami karya baik secara bentuk, isi dan latar terciptanya seni tersebut.

Pembelajaran apresiasi dapat dilakukan dengan penyajian karya meliputi kegiatan penyajian lisan dalam diskusi kelas dan pameran baik dalam lingkup kelas, sekolah, maupun masyarakat. Diskusi kelas bertujuan untuk menampilkan, mempresentasikan, dialog tentang hasil karya dan proses kreatif yang dilakukan siswa. Kegiatan diskusi ini dapat pula dipadukan dengan kegiatan penyajian lisan. Penyajian tulis dalam bentuk mendiskripsikan hasil karya keterampilan. Penyajian dalam bentuk pameran karya dalam lingkup kelas bertujuan untuk menampilkan hasil karya kreasi siswa dalam rangka apresiasi di lingkungan siswa sekelas, sekolah, atau pada masyarakat umumnya. Pembelajaran apresiasi dapat pula sebagai pembelajaran kritik seni. Peserta didik diajak untuk memahami produk seni dan kerajinan melalui kegiatan mendeskripsikan karya seni dan kerajinan secara kritis dari apa yang diamati. Peserta didik dapat melakukan analisis terhadap karya seni dengan membedah komposisi, proporsi, tektur, dan kerindahan karya dengan cermat. Kegiatan intepretasi dengan cara memberikan keputusan hasil deskripsi dan analisis bahwa karya seni tersebut memiliki bobot atau kurang berbobot berdasarkan hasil analisis secara objektif. Tingkatan terakhir dari proses kritik adalah memberikan keputusan evaluasi untuk menentukan bahwa karya seni tersebut memang indah, berbobot atau kurang bermutu dan memberikan rekomendasi untuk menindak lanjuti dalam kerangka untuk membangun dan memperbaiki proses dan hasil karya. Pembelajaran keterampilan dibedakan menjadi pembelajaran apresiatif dan pembelajaran kreasi atau produktif. Pembelajaran apresiatif meliputi apresiasi proses dan hasil karya. Pembelajaran apresiasi di sekolah dapat dimulai dari apresiasi karya ciptaan siswa, karya ciptaan orang lain baik tradisional maupun modern. Melalui pembelajaran apresiasi ini diharapkan siswa memiliki wawasan pengetahuan yang luas, pe- 
mahaman, tentang produk keterampilan.

Pelaksanaan pembelajaran keterampilan di sekolah alternatif yang dapat dilaksanakan sesuai konteks dan kemampuan sekolah atau daerah sebagai berikut. Sekolah yang memiliki guru keterampilan yang lengkap kerajinan dan teknologi dapat melaksanakan pembelajaran keterampilan secara terpisah sesuai bidangnya. Siswa diberikan kebebesan memilih bidang keterampilan tertentu sesuai minatnya. Untuk pelaksanaan pembelajaran terpadu (misalnya kerajinan dengan elektronika) dapat dilaksanakan berkerja sama dalam bentuk pembelajaran bertim untuk melaksanakan pembelajaran model tertentu, sehingga menghasilkan karya kerajinan dengan sentuhan teknologi. Karya tersebut dapat berbentuk robot, kendaraan tradisional, boneka tradisional yang dapat digerakan oleh tenaga listrik baik arus lemah maupun kuat. Sekolah yang hanya memiliki satu guru bidang keterampilan tertentu, guru tersebut melaksanakan pembelajaran sesuai dengan bidangnya, tetapi juga diharapkan mengajarkan bidang keterampilan yang lain menurut kemampuannya untuk memberikan wawasan apreasiasi kepada peserta didik. Sekolah yang belum memiliki guru keterampilan pelajaran keterampilan dapat dipegang oleh guru mata pelajaran lain yang memiliki minat dan kemampuan pada bidang keterampilan tertentu.

Materi pembelajaran yang bersifat teoretik sebaiknya tidak diberikan secara terpisah, melainkan diberikan secara terpadu dengan materi kegiatan apresiatif dan berkarya seni. Materi pelajaran praktik berkarya seni kerajinan menekankan aspek proses dan hasil. Oleh sebab itu, pembelajaran lebih menekankan pada usaha membentuk pemahaman dan mengungkapkan gagasan kreatif. Pada dasarnya jika proses dilakukan dengan prosedur yang benar, baik, logis, akan dihasilkan produk karya seni yang baik pula. Pembelajaran keterampilan kerajinan yang lebih profesional penguasaan bidang tertentu misalnya kerajinan (batik, kayu, bambu), sekolah dapat melaksanakan kegiatan pembelajaran melalui mulok kerajinan atau ektrakurikuler kerajinan sesuai pilihan peserta didik.

Pembelajaran keterampilan dapat menggunakan berbagai model sesuai dengan kebutuhan dan kelayakan sekolah. Diknas telah memprogramkan pembelajaran bebebasis kompetensi menggunakan pendekatam CTL sesuai kontek sekolah, daerah, dan kemampuan peserta didik. Diknas juga menerapkan pendekatan life skills dalam pembelajaran berbasis kompetensi untuk memberikan bekal kecakapan hidup lulusan agar dapat mengatasi permasalahan hidup di lingkungan masyarakatnya dengan wajar. Dengan CTL dan life skills diharapkan lulusan mampu menghadapi permasalahan hidup dan kehidupan secara nyata sesuai dengan konteks sosial budaya meraka berada.

Pembelajaran keterampilan dengan model apapun hendaknya tetap menggunakan strategi tatap muka dan memberikan pengalaman belajar learning by doing. Strategi tatap muka adalah bentuk kegiatan interaksi aktif guru dan siswa dengan bentuk atau cara diskusi, 
presentasi, tanya jawab, demontrasi, dan lain-lain yang dapat mengaktifkan dan mengefektifkan komunikasi guru dan siswa untuk menanamkan nilainilai humanistik kepada peserta didik. Kegiatan interaksi aktif dapat di dalam kelas, di laboratorium, di lapangan dan sebagainya di mana proses transfer pengetahuan dan keterampilan dilakukan. Pengalaman belajar adalah sebuah kegiatan siswa berinteraksi dengan bahan ajar untuk menguasai kompetensi tertentu baik secara mandiri maupun trstruktur di bawah bimbingan guru. Bagaimana siswa menguasai pengetahuan dan keterampilan melalui berinteraksi dengan bahan ajar. Dalam proses tatap muka maupun pengalaman belajar guru berfungsi sebagai fasilitator dan motivator bagi siswanya, bukan pemberi materi pelajaran. Dalam proses itu bagaimana guru membimbing agar siswa dapat berkembang dengan baik dan menyenangkan.

Dalam kegiatan interaksi guru siswa dalam bentuk tatap muka yang perlu diperhatikan adalah sebagai berikut.

- Mengkondisikan kelas untuk menyiapkan secara fisik dan mental agar dapat mengikuti program pembelajaran dengan baik.

- Memberikan informasi yang jelas akan tugas yang harus dikerjakan siswa.

- Memberikan tugas yang dapat memberikan pengalaman belajar yang menarik dan baru sesuai dengan perkembangan dan kebutuhan siswa.

- Mendemontrasikan cara membuat atau melakukan suatu dengan baik sehingga dapat memberikan keya- kinan pada siswa bahwa guru dapat berkarya atau melakukan sesuatu dengan baik.

- Menggunakan media yang menarik sehingga dapat memberikan pengalaman baru bagi siswa.

Dalam kegiatan pengalaman belajar pada prinsipnya adalah kegiatan yang diarahkan agar peserta didik menguasai kemampuan dan keterampilan berinteraksi langsungg dengan bahan ajar atau tugas mandiri yang diberikan guru. Dalam membangun pengalaman belajar peserta didik, perlu difasilitasi bagaimana anak mencari dan menemukan sesuatu pengetahuan dan keterampilan dengan caranya sendiri. Ada beberapa prinsip yang penting yang harus dilakukan oleh siswa adalah sebagai berikut.

- Berikan kebebasan untuk memilih tema/motifbentuk seni tradisi daerah setempat sesuai dengan keinginan siswa dalam kontek wilayah tugas yang diberikan oleh guru.

- Berikan bimbingan dan pengawasan yang cukup agar siswa terkendali dalam proses melakukan pengalaman belajar

- Berikan dorongan dan kritik yang membangun sehingga siswa akan lebih berkembang dan percaya diri

- Dekati secara individual apa keinginan dan kesulitan mereka

- Jangan memaksakan keinginan guru dalam proses berkarya siswa dalam kontek isi karya bukan keteknikan

- Dalam pembelajaran guru ikut berkarya bersama siswa dapat memberikan kepercayaan dan motivasi belajar yang efektif. 


\section{PENUTUP}

Lulusan pendidikan kita secara umum belum memiliki kecakapan hidup yang cukup untuk terjun di masyarakat. Oleh sebab itu, dengan kebijakan otonomi daerah, sekolah diberikan kewenangan penuh untuk mengembangkan pendidikan sesuai dengan budaya masyarakat setempat seperti yang telah digariskan dalam standar isi Kurikulum Berbasis Kompetensi (KBK) dalam kemasan kurikulum tingkat satuan pendidikan. Perbaikan kurikulum perlu juga diikuti perubahan yang lain seperti sarana penunjang, perbaikan fasilitas, perbaikan prestasi guru, dan perubahan budaya mengajar.

Pada prinsipnya pembelajaran keterampilan di sekolah secara konseptual dibagi menjadi dua yaitu pembelajaran apresiatif dan pembelajaran produktif. Pembelajaran apresiasitif dapat dilakukan melalui pembelajaran berkarya kerajinan, kritik seni, dan penyajian karya. Pembelajaran produktif dapat dilakukan dengan mengembangkan seni kerajinan daerah setempat yang dikemas lebih sederhana dan menarik sesuai perkembangan anak. Pembelajaran keterampilan kerajinan yang baik dapat mengembangkan kecakapan hidup peserta didik untuk bekal hidup di kemudian hari. Model pembelajaran keterampilan kerajinan dapat dikembangkan dengan menggunakan metode $3 \mathrm{~N} / 3 \mathrm{M}$ atau ATM agar anak terlibat langsung berkarya kerajinan dengan baik Selain itu, pembelajaran keterampilan kerajinan harus disesuaikan dengan kemampuan sekolah, kemampuan guru, dan kebutuhan masyarakat. Hal penting yang harus dilakukan guru dalam pem- belajaran adalah berperan sebagai fasilitator dan motivator bagi anak didiknya agar dapat berkembang dengan baik. Model pembelajaran apa pun yang dikembangkan harus dapat memberikan pengalaman belajar yang menyenangkan bagi anak, sehingga tujuan pembelajaran kerajinan dapat tercapai dengan baik. Menciptakan situasi belajar yang baik dan kondusif dapat mendorong anak untuk belajar dengan baik. Model pembelajaran yang baik dimulai dari guru yang baik, guru yang baik adalah guru yang mau menerima perubahan dan mau berubah dengan penuh kesadaran. Pembelajaran keterampilan kerajinan harus mampu mengembangkan dan melestarikan seni tradisi daerah setempat.

\section{UCAPAN TERIMA KASIH}

Terima kasih diucapakan kepada semua pihak yang telah memberi kontribusi terhadap artikel ini. Terima kasih juga diucapkan kepada pengurus dan Redaktur Jurnal Cakrawala Pendidikan.

\section{DAFTAR PUSTAKA}

Depdikbud. 1996. Kurikulum Sekolah Menengah Kejuruan,Landasan, Program dan Pengembangan.

Depdikbud. 1997. Ketrampilan Menjelang 2020 untuk Era Global. Jakarta.

Diknas.2000. Standar Isi. Jakarta: BSNP. 
Dimyati. 1999. Belajar dan Pembelajaran. Jakarta: Rineka Cipta.

Djelantik A.A.M. 1999. Estetika sebuah Pengantar. Bandung: MSPI.

Djojonegoro, Wardiman. 1998. Pengembangan Sumber Daya Manusia melalui SMK. Jakarta: Depdikbud.

Djohar. 1999. Reformasi dan Masa Depan Pendidikan di Indonesia. Yogyakarta: IKIP.

Hamalik, Umar. 1994. Pengembangan Kurikulum dan Pembelajaran. Bandung: Trigenda Karya.

Joyce, Weil. 1996. Models of Teaching. Boston: Allyn and Bacon.

Lansing, M.Kenneth. Art, Artists, and Art Education. New york: Mc Graw-Hill Book Company.

Larkin, Diarmuid. 1981. Art Learning and Teaching. Melbourne: Cassell.

Mattil, Edward. 1971. Meaning in Craft. New Jersey: Prentice Hall.

Mulyasa. 2003. Kurikulum Berbasis Kompetensi, Konsep, Karakteristik, dan Implementasinya. Bandung: Rosda.

Peraturan Pemerintah Nomor 19 Tahun 2005 tentang Standar Nasional Pendidikan.
Pidarta Made. 1997. Landasan Kependidikan. Jakarta: Rineka Cipta.

Rohidi, Rohendi Tjetjep. 2000. Kesenian dalam Pendekatan Kebudayaan. Bandung: STISI Press. - 1994. Pendekatan Sistem Sosial Budaya dalam Pendidikan. Semarang: IKIP Press.

Soedarso. 1987. Tinjauan Seni sebuah Pengantar untuk Apresiasi Seni. Yogyakarta: Sakudayarsana.

Tilaar HAR. 1999. Pendidikan, Kebudayaan, dan Masyarakat Madani Indonesia. Bandung: Remaja Rosda Karya. 1999. Beberapa Agenda Reformasi Pendidikan Nasional dalam Perspektif Abad 21. Magelang: Tera Indonesia.

UU Tahun 2003 tentang Sistem Pendidikan Nasional.

Winkel WS. 1987. Psikologi Pengajaran. Jakarta: Gramedia 